\title{
Employment institutions under liberalisation pressures. Analysing the effects of regulatory change on collective bargaining in Spain.
}

\begin{abstract}
This article discusses the effects of regulatory change in employees' working conditions and the dynamics of collective bargaining in Spain, a model affected by a drastic regulatory change, and draws a comparison with the UK, the more deregulated and single-employer bargaining model in Europe. The comparison is carried out using EU-SILC panel data to identify commonalities and differences in the patterns of change in salaries and working hours. Second, national data from Spain is used to analyse the impacts of reforms on the characteristics and outputs of collective bargaining. The findings show that regulatory changes provoked a drastic adjustment in wages in Spain, following patterns similar to the British model. However, the results lead us to highlight the need to enhance knowledge about the dynamics of bargaining processes as they crucially reveal that these trends are happening in mostly unchanged institutional characteristics.
\end{abstract}

Key words: collective bargaining, liberalisation, austerity

\section{Introduction}

This article analyses how the reform of collective bargaining system in Spain affected the characteristics and processes of joint regulation. Collective bargaining has been at the forefront of the changes in employment regulation in the aftermath of the economic recession (Deakin and Koukadaki, 2013). After the period of fiscal stimuli that characterised the management of the first stage of the 2008 recession, the second phase of the crisis, characterised by fiscal austerity and the re-regulatory role of supranational economic and political institutions, aimed to reframe the crisis as a product of intervention and regulation (Heyes et al, 2012). This ideological reframing of the downturn targeted joint regulation institutions and advocated to facilitate adjustments through salary and working conditions. In this regard, the patterns in collective bargaining have been one of the main targets of the reforms, especially in those countries under the conditions of the 'Troika' (Koukiadaki et al. 2016), namely the European Commission, the European Central bank and the International Monetary Fund. And, as has been recently argued by Visser (2016: 1), "a more exclusive version based on enterprise bargaining have been favored by the governments and international agencies." Moreover, the public sector has suffered significant cutbacks, and the working conditions and salaries of its workers have been frozen or reduced (Vaughan-Whithead, 2014). Finally, and a particular interest of this paper, the milestone of these policies have been increasing pressures on collective wage-setting mechanisms to become more 'marketized' (Marginson and Welz, 2015). In those countries in receive of some sort of financial aid an essential feature of the reforms has been the bypass of social dialogue and the unilateral role of the State in reshaping collective bargaining. Following Meardi (2014), the role of European level institutions in imposing the austerity narrative allowed governments to carry out drastic reforms that the balance of power would not have permitted.

The Spanish labour market was, and still is, strongly suffering the effects of the 2008 recession. The country entered recession after a period of economic and employment growth that started in 1996, characterised by the predominant role of the construction sector and the development of a significant housing bubble (Banyuls et al, 2009; López and Rodríguez, 2011). During the period of economic growth, employment increased by more than 7,700,000 jobs $\mathrm{s}^{\mathrm{i}}$. The recession then led to rapid loss of jobs and increase of unemployment (Muñoz de Bustillo and Anton, 2011). From 2007 to 2010 the unemployment rate skyrocketed from $8.2 \%$ to almost $20 \%$ and more than 1,800,000 jobs were lost, accounting for $42 \%$ of all job losses of the EU-27 in the period. In this context, the narratives that remarked in high ideological terms the lack of flexibility of the Spanish model gained momentum (Fernández Rodriguez and Martínez Lucio, 2013), and 
reforms were carried out by different parties in office that drastically modified the system of collective bargaining.

Taking its cue from MacKenzie and Martinez Lucio (2005 and 2014), this article considers that these reforms have modified the regulatory space of collective bargaining in Spain by reordering levels of regulation and by jeopardising practices and linkages between actors. The purpose of the article is to discern how the changes in the regulation of collective bargaining affected the dynamics of industrial relations in Spain and aims to enhance the knowledge about the effects of regulatory changes in the employment relationship. To carry out these objectives the article uses, first, the EU-SILC panel data to investigate the changes in salary and working hours of employees in the same job in three periods (before the crisis, during the crisis and after the implementation of austerity policies). Here a comparison between Spain and the UK is carried out to observe commonalities and differences in patterns of change in the UK. This is an important comparison because it allows us to identify differences and commonalities between a market-led model, like the British one, and a multi-employer model under pressure, like the Spanish one. The reforms implemented at national level and promoted by European institutions aimed to develop a decentralised system of collective bargaining as a way to promote flexibility adjustments at company level in South-European countries (Schulten and Müller, 2015). Hence, the comparison allows us to identify the patterns of change in salaries and working hours of the Spanish model with the British model, the main market-led model in Europe. Second, using national data on patterns in collective bargaining the article discusses the effect on industrial relations dynamics in Spain during the period of institutional change.

The article is organised as follows. In the first section, main trends in employment institutions and collective bargaining during recession and austerity are discussed. The second section describes the main changes to the system of collective bargaining in Spain, while in the third section the methods used in the article are introduced. The fourth section presents the results and deals with the major objectives of the article. Finally, in the last section, main findings are discussed, and the relevance of the results for current debates on changes in institutions are considered.

\section{Multi-employer collective bargaining under pressure}

Since the 1990s the literature on industrial relations has identified a common trend towards the decentralization of collective bargaining, following two main paths: 'organized' and 'disorganized' decentralization (Traxler, 1995; Marginson and Sisson, 2004). In the former, characteristic of the so-called Coordinated Market Economies (CMEs), the the space for firmlevel negotiation is created and regulated within the framework of multi-employer agreements. In the latter multi-employer agreements lose their capacity to provide frames to lower levels and typically relates to Liberal market Economies (LMEs). These different paths acknowledge the relevance of various institutions and embedded practices existing in different countries (Locke and Thelen, 1995). However, even in the case of countries following the 'organized' decentralization path, the consequence has been an incremental corrosion of multi-employer bargaining in which the substantive contents of multi-employer agreements have diminished and have tended to establish basic minimum standards (Marginson, 2014). Furthermore, the use of these ideal types is problematic. The differences within each group are underestimated (Jackson and Deeg, 2008) and the LME/CME dichotomy leaves out most of the world economies (Almond, 2011). In this regard, these typologies should be taken with caution and is necessary to consider the unique architecture of national employment models.

Against this framework, the 2008 recession challenged these existing patterns of joint regulation. In the first phase of the crisis, responses were shaped by the institutional characteristics of national employment regimes (Heyes, 2013). In countries characterised by well-coordinated multi-employer bargaining systems, sector and inter-sector agreements provided substantive procedures (such as short-time work schemes supported by public policy) 
and certainty at firm level (Crouch, 2014). Conversely, unilateral employer responses were widespread in countries with single-employer bargaining arrangements, such as the UK, and in countries in which the vertical coordination between sector-level agreements and firm-level was not clearly established, like Southern European countries (Glassner et al, 2011; Lallement, 2011). Accordingly, in the first group of countries, adjustments were mainly done by working time, while in the second group this was mostly made by increases in unemployment, underemployment, and labour market segmentation, the latter especially in South European countries. Therefore, different routes of deregulation can be identified (Prosser, 2015). Accordingly, in South European countries, processes of liberalisation are developed in parallel with high levels of unemployment, precarious work and informality, what difficult the regulatory role of unions.

The trends outlined above accelerated during the second phase of the crisis. The 'austerity turn' re-framed the crisis as a product of intervention and regulation (Heyes et al., 2012) and pressures from employers and public authorities towards further 'marketization' of collective wage-settings increased (Hermann, 2014; Marginson and Welz, 2015). In this regard, Marginson (2014), Marginson et al. (2014) and Visser (2015) have identified two types of countries. In CMEs and the Nordic countries the process of organized decentralization has been accelerated by actors' practices and changes have been concerted; on the other hand, in countries either subject to international financial rescue packages (Greece, Portugal and Ireland) or coming under severe pressures from financial markets (Italy and Spain) the existing patterns of collective bargaining arrangements have been modified and the capacity of multi-employer agreements to govern bargaining at firm-level has been diminished (Marginson, 2014; Koukiadaki et al., 2016). In this last group of countries, the reforms were contested by organized labour and imposed by the government, who played a crucial role in shifting the power boundaries at the national level (Meardi, 2014).

The interpretation of these trends is a matter of discussion (see Thellen, 2014 and Prosser, 2015). The first line of thought is related to the Varieties of Capitalism (VoC) literature and argues that responses to exogenous shocks will differ between different institutional settings (Iversen, 2007 and Hall and Gingerick, 2009, among others). These authors highlight the vitality of the differences between LMEs and CMEs. Following this perspective, Thellen (2014) has discussed the role of changes in institutions that shape different employment models, including collective bargaining. She has also pointed out that instituions survive best not by reproducing the stability of the models, but when they are reconfigured in form and function on the basis of significantly new political support coalitions. A second line of arguments has identified a common trend towards liberalisation, identified as a part of a neoliberal project to undermine the role of organised labour and practices of joint regulation (Howell, 2003; Baccaro and Howell, 2011; Hermann, 2014; among others). This body of work recognises the existing institutional differences, but argues that liberalisation has not been restricted to liberal economies (Heyes, 2013) and that a common neoliberal trajectory in industrial relations, implying greater employer discretion, can be identified within all models. In this sense, Baccaro and Howell (2011: 526-527) have identified two different movements. The first, related with institutional processes, involves the elimination or relaxation of institutional barriers and constraints on capital discretion (deregulation). This includes the decentralization and individualization of collective bargaining and measures such as bypass mechanisms. The second has to do with institutional outcomes and the transformation in the role played by formally unchanged institutions from discretion-limiting to discretion-enhancing (institutional conversion). Significantly, the first approach prioritises the characteristics of collective bargaining (levels of coordination, coverage, etc.) and highlights the autonomy of the political sphere and the State in terms of policies and in building coalitions. Conversely, for the second approach, the key element is the outcome of processes within institutional architectures. Accordingly, the State played a key role in re-regulating employment relations and reinforcing the role of the employer in the workplace and in society (Heyes et al., 2012; Howell, 2016). 
The interface between the institutional level and the dynamics and processes that shape the characteristics and outputs of collective bargaining is a milestone in the analysis of regulatory changes. The approach taken in this article follows MacKenzie and Martinez Lucio (2014) by considering that changes in the regulatory context can modify the sites or levels of regulation, the actors in the regulatory space, and the boundaries of power and formal and informal linkages between actors. Therefore, it is understood that the motor of a regulatory change is usually related to a shift in the concrete and (political) regulatory agenda that was the basis of the formal and informal linkages between actors (MacKenzie and Martinez Lucio, 2005). Accordingly, an analysis of the effect of a regulatory change in collective bargaining should focus on how the different levels of regulation and the linkages between levels are re-organised, but it should also pay special attention to the processes and shifts in actors' power relations within the regulatory space and how this affects the dynamics of collective bargaining.

\section{The reform of collective bargaining in Spain}

The collective bargaining system in Spain before the reforms was characterised by high comparative rates of coverage and by the coordinator role of multi-employer national or provincial sector-level agreements (Fernandez Rodriguez et al., 2016). This sectoral level of bargaining established basic conditions for workers covered (Hamann, 2012), which together with the so-called 'after-effect' of the agreements ${ }^{\mathrm{ii}}$, grounded the continuous extension and high coverage of collective bargaining. Moreover, Spanish unions had a relatively low structural power due to the high unemployment and temporary contract rates, the weight of small and medium sized companies, and the constant restructuring of the Spanish economy since the 1980 s, that affected core industrial sectors with a traditional strong union presence (Calavia and Rigby, 2016). Furthermore, they showed a low associational power (membership) even though participation in the elections for Works Councils was high. This made the application of multiemployer and social dialogue agreements at company level difficult (Hamann and Martinez Lucio, 2003). In terms of institutional power this remained high and the State was key in bringing legitimation to industrial actors and the bargaining process (Molina, 2014). However, the system was fragmented and showing regulatory gaps, especially in the transference of the contents of social dialogue multi-employer agreements to small and medium-sized enterprises (Martinez Lucio, 1999). Moreover, the system was far from being well articulated and coordinated (Fernandez Rodriguez et al., 2016). Accordingly, and following Molina and Rhodes (2007) typology of the Mediterranean model, Spain is a hybrid system in which the State plays a key role in industrial relations, and labour relations are fragmented.

The 2008 recession strongly hit the Spanish labour market. The dramatic increase of job losses, concentrated in temporary jobs during the first phase of the crisis (Muñoz de Bustillo and Antón, 2011), reinforced labour market segmentation (Lallement, 2011). In this context, and under the risk of a bailout of the Spanish economy, the Socialist party in power in 2010 made a U-turn in the way the crisis was being managed and introduced a package of measures with a neoliberal slant, including the reform of collective bargaining (Banyuls and Recio, 2015). These reforms were deepened in even a more radical way in 2011 and 2012 by the conservative People's Party in office. The reforms radically developed some of the historical demands of the more neoliberal side of employer organisations and, more crucially, the external pressure of EU institutions were used to bypass well-established practices of social dialogue (Molina and Miguélez, 2013). This lack of legitimacy of the measures brought Rocha (2014) to consider that industrial relations in Spain are becoming more authoritarian, as unilateral decentralization is established by State imposition and by leaving aside social dialogue and social actors

These reforms deeply modified the regulation of collective bargaining. First, the existing structure of collective bargaining was changed, in a movement that can be defined towards 'disorganised decentralisation' (Marginson et al., 2014). Accordingly, priority was given to company-level agreements over multi-employer agreements in working conditions. At the same time, a limit of 2 years was fixed for the 'after-effect' (known as pluriactividad in Spanish), 
with an extraordinary period of validity of the finished agreements until 2012. Second, the reforms strengthened employer-driven flexibility in working conditions. The unilateral capacity of the employer to change working conditions was enhanced by allowing changes to be made in the case of mere expectation of future losses and the options for an employer to 'opt out' from existing agreements (salaries and working time) were made possible after two consecutive trimesters of revenue decreases. Furthermore, the reforms made possible for the employer to unilaterally introduce 'internal flexibility' in working time and tasks without the need to negotiate. Finally, a new working time reduction scheme was introduced that since 2012 can be unilaterally imposed by the employer if causes for objective dismissal concur. Under this scheme, a worker with contributory rights can use unemployment benefit during the period 'redundancy' to complement the salary affected by the reduction in hours.

In parallel, measures were introduced to make dismissals and redundancies easier, that further undermined the power of unions at workplace level (López-Andreu, 2017). These measures included the broadening of causes for objective dismissal (with lower redundancy payment), reduced dismissal costs for compensation in case of 'unfair' dismissal, the introduction of a new open-ended contract for certain circumstances with one year of probation and subject to employer' discounts in social security and subsidies, and the removal of the required administrative authorization for collective dismissals (ERE). The latter acted as an incentive for firms to negotiate collective dismissals and for unions to improve conditions (Banyuls and Recio, 2014) ${ }^{\text {iii }}$. Moreover, public sector employment suffered significant cutbacks, including a $5 \%$ wage cut in 2010 and a freeze until 2016, and a virtual freeze on new hiring, among other measures (Muñoz de Bustillo and Antón, 2013).

\section{Methods}

The data used in this article aims to answer two main questions. The first is to compare the effect of recession and austerity in salaries and working hours in Spain and the UK. This comparison pursuits to identify how the Spanish model -characterised by being a multiemployer model and with high coverage but affected by a drastic regulatory change-, and the British liberal model reacted to recession and austerity. This comparison uses the British model as an extreme example of liberal model in Europe. Conversely, Spanish case is not used as an example of a multi-employer model, Moreover, it is discussed as a good case that allow us to capture the complexity of the effects of a regulatory change. To achieve this goal this article uses the EU-SILC panel data provided by Eurostat to undertake a unique analysis that provides evidence of the effects of the regulatory change on salaries and working hours in both countries. This is relevant as there are no many studies available that provide this kind of data. The EUSILC permits to undertake analysis in the diachronic perspective, which is indispensable when examining changing in salaries and working hours. Furthermore, it is the only available longitudinal data that covers a broad number of European countries, including Spain and the United Kingdom. The panel data covers a maximum of four years and permitted us to carry out the analysis in three periods: pre-recession (2004-2007, but 2005 in the UK as EU-SILC did not start until 2005), recession (2007-2010) and austerity (2010-2013). Using this data set two variables are used to identify changes between $t-1$ and $t$ in salary and working hours. The salary is calculated using the variable 'Gross employee cash or near cash income', which accounts for annual salary, and the working hours using the variable 'Number of hours usually worked per week in main job'.

The analysis is restricted to employees between $\mathrm{t}-1$ and $\mathrm{t}$ who did not change job in the period. Therefore, the analysis is carried out considering the change in salary and working hours between two years of employees in the same job. The data set permitted to identify a minimum of two and a maximum of three observations per individual in each period of analysis. Furthermore, salary changes were divided into three groups in relation to inflation for each year $^{\text {iv }}$ : 1) Real salary increase, when the salary increased above the inflation, 2) Nominal salary increase or no change, when the salary increased equal or below inflation or there was no 
change; and 3) Salary decrease. In the Spanish case inflation was negative in 2009 and, in this situation, any salary increase was considered as real salary increase, any decrease above inflation nominal increase, and any decrease below inflation salary decrease.

The next step was to cluster the changes in salary and working hours in different combinations:

1. Real salary increase and no change or working fewer hours;

2. Real salary increase and working more hours.

3. Nominal salary increase or no change in salary and no change or working fewer hours;

4. Nominal salary increase or no change in salary and working more hours;

5. Salary decrease and working fewer hours; and

6. Salary decrease and no change or working more hours.

The second objective is to analyse the characteristics and dynamics of collective bargaining during the recession and reforms (austerity) in Spain. To this aim this article uses Spanish data on collective bargaining to identify main patterns regarding the levels, coverage and outputs of collective bargaining, following main discussions in section 1 . The main data base used here is the Statistics on Collective Bargaining, provided by the Employment and Social Security Ministry. This data is based in the compulsory registration by industrial actors of collective agreements. As discussed by Pérez-Infante (2015), the data has some limits: First, the extension of existing agreements under the 'after-effect' and the agreements without pay-settings are not included in the data; and second, the data about the number of workers covered by the agreement are self-calculated by social actors, and can be overestimated. However, it is the official data and is the most reliable source regarding collective agreements. Moreover, these limitations affected all years so it is an adequate tool to identify trends and changes.

\section{Findings}

The results are divided into two sections. In the first section, changes in salary and working hours in the three selected periods in Spain and the UK are discussed, while in the second the characteristics and dynamics of collecting bargaining in the periods considered are analysed.

\section{Changes in salary and working time during recession and austerity in Spain and the UK}

Using the EU-SILC data on annual salary and normal weekly working hours Table 1 permits us to identify changes in relation to the previous year in the periods considered. The figure reveals the differences between the two countries, but some common trends in the patterns of change after the regulatory change started in 2010 in Spain.

[Figure 1 about here]

Before the crisis, the most common situation in Spain was a real salary increase, affecting about $55 \%$ of employees in the same job between two years. The increase in salary mostly affected people working the same or fewer hours than the previous year $(40.7 \%)$. The real progression in pay is related to the coordinator role of sector-level agreements, which usually established inflation and above inflation increases with a duration period of several years. In spite of that, it is worth noting that in this period about a third of employees reported a lower salary than in the previous year. Turning to the situation during the recession (2007-2010), the share of employees showing a real salary increase does not change too much in comparison with the preceding period. In this regard, we can argue that job losses in the recession period were focused on workers less likely to be affected by real salary increases (more precarious jobs). In line with the reinforced segmentation hypothesis (Lallement, 2011), in this first phase precarious and temproary jobs were the bulk of the adjustment, and as these employees are less likely to 
experience real salary increases the outcome is that the shar eof employees showing a real slaary increase remains stable.

The situation drastically changes in the austerity period (2010-2013). Here we can identify a clear effect of the changes at the institutional level. In this period, the percentage of employees affected by a real salary increase fell by more than 15 points in comparison with the 2007-2010 period, descending from the $55.7 \%$ to the $40.3 \%$. This seems to affect proportionally both those working same or fewer hours and those working more hours than the previous year. Conversely, employees affected by a salary decrease grew in 10 points and increased up to $46.4 \%$, and those reporting a nominal salary increase or no change increased by 5.4 points. The increase of employees affected by a lower salary than the previous year is related to a slight increase of 2.8 points for those working fewer hours, but to a more important increase of 7.2 points for employees working the same or more hours. The latter shows that the bulk of salary decrease has concentrated in reducing salaries and is less related to working time adjustments. Unfortunately, EU-SILC longitudinal data does not include information on the economic sector. However, using the Spanish data from Structure of Earnings Survey, which includes annual earnings of employees by sector, we identify that in the 2010-2013 period the higher falls in salaries affected workers in health and social services (-5.8\%), followed by hospitality $(-5.3 \%)$, financial and insurance activities $(-4.9 \%)$, real estate $(-3.6 \%)$ and, finally, public administration $(-1.1 \%)^{\mathrm{v}}$.

In the case of the UK the share of employees showing a real salary increase before the recession was almost the same as in Spain. However, the pattern of real salary increase was more closely related to an increase in working hours than in Spain (20.6\% against 14.6\%). The latter shows the long working hours culture that characterizes the British labour market (Rubery and Girmshaw, 2003). Furthermore, the percentage of employees with a salary decrease was higher and more related to work of less working hours than the previous year than in Spain, due to the importance of working hours as a quantitative adjustment in the labour market (Warren, 2015). The low coverage of collective agreements permitted British employers to adapt salaries and working hours with ease during the recession (Van Wanrooy et al., 2014). Accordingly, in the 2007-2010 period employees affected by a salary decrease grow by almost 9 points in comparison with the previous period, from $37.3 \%$ to $46.1 \%$. In this case, the salary adjustment tended to be linked to work fewer hours. On the other hand, the 6.7 points of increase in employees affected by a real salary decrease is related to those employees working the same or fewer hours. In the 2010-2013 period, and despite that the economy and the employment started to recover at the end of 2011, the trend towards a salary decrease persisted. The application of the austerity policies in the public sector (in forms of salary freezing, increased outsourcing and fewer rights in case of transfer of undertakings; Grimshaw, 2012) and a general erosion of employment rights (Grimshaw and Rubery, 2012) led to a further fall in employees showing a real salary increase by more than 2 points.

In relation to our comparative purposes, and as discussed in the existing literature, the panel data has shown that in a market-oriented system like the British one, salaries and working hours have changed with ease during the economic downturn. Furthermore, in the context of the recession, the working conditions of British employees were drastically adjusted by reducing salaries and, to a lesser extent, working hours, accordingly to the important power that employers have at workplace level. This situation persisted during austerity despite the formal recovery. Conversely, the salaries of Spanish workers in employment did not change substantially during the recession, due to the existing practices of joint regulation. However, a deep change occurred during austerity. In this latter period the reforms led to lower salaries, not especially related to working fewer hours. Crucially, the data suggests that after 2010 Spanish employees suffered similar (or even more) changes in their salaries than the British ones. Furthermore, these changes in Spain occurred in parallel to massive job losses and redundancies, as job losses persisted until late $2014^{\text {vi }}$. The next section analyses the processes and dynamics behind these changes. 


\section{The characteristics and dynamics of collective bargaining in Spain}

The changes in the regulation of collective bargaining in Spain have implied a regulatory movement towards the prevalence of firm-level agreements, the reinforcement of employers' capacities to modify working conditions with ease, and increased options for employers to opt out from existing agreements. The data in the previous section has shown that after 2010 the changes had a clear effect in provoking a decrease in salaries. Therefore, the aim of the reform of the Spanish system of collective bargaining -to develop more firm-level adjustments as a way to cope with economic circumstances like in the British market-led model- seems to have been achieved. However, the processes and dynamics through this aim was achieved need a detailed analysis. In this section, we pay attention to the effect of the regulatory change in the levels of characteristics and the dynamics of collective bargaining.

Table 2 shows data about collective agreements in force, the percentage of firm level on total agreements, and the total coverage of collective agreements.

[Table 1 about here]

At first glance, the data shows that the priority given to firm-level agreements led to some relevant but not dramatic changes in the structure of collective bargaining in 2014 and 2015. Existing research has identified a shift in the composition of multi-employer agreements from provincial level to regional and national level and it has found that there has not been a significant increase in single-employer agreements (Malo, 2016). In our data for 2014 and 2015 (the last with definitive data), the percentage of firm-level agreements on total agreements increased by more than 3 points in 2014 and by more than 2 in 2015 . However, the percentage of workers affected by firm-level agreements decreased in both years, suggesting that the increase of firm-level agreements is related to more small companies than in the past. In this sense, these new firm-level agreements may have been reached by small companies, probably downgrading the conditions agreed at sector level as permitted by the new regulation. This is an important trend that should be further investigated once more data will be available due to the prevalence of the small and medium sized enterprises in Spain.

Second, the data shows that the coverage of collective agreements remained relatively stable. In the first years of the recession (2008 and 2009), the coverage increased as job losses tended to be focused on workers not covered by agreements. On the other hand, once the reforms started (2010), the coverage declined between 4 and 5 points up to its lowest figure in 2012, to further increase in 2013 and 2014. The coverage slightly falls again in 2015 probably related to the end of some multi-employer agreements (traditionally with a duration period of two years) reached between 2012 and 2013. Overall, this data suggests certain stability and resilience of the system of collective bargaining to the regulatory changes, and opens the question about how the drastic salary decreases identified in the period have been achieved. A more detailed analysis of the dynamics behind these figures can help us to fully understand the changes in the processes and interactions between actors. First, while agreements reached annually declined during the crisis, the coverage was not affected due to an increase in retroactive agreements. The available data shown in the last column of Table 1 shows that, without the retroactive agreements (these are agreements reached after the year their economic effects started) in 2012, the coverage would have been much lower (about 54\%). Furthermore, in 2012 retroactive agreements skyrocketed and reached a peak, especially in multi-employer agreements, accounting for $26.7 \%$ of all agreements in force for 2012, in contrast with $16.6 \%$ in 2011, 9.9\% in 2009 and, on the other hand, $10.5 \%, 9.4 \%$ and $8.1 \%$ in 2013, 2014 and 2015 (own calculation by the author using the Statistics on Collective Agreements, INE).

Moreover, in 2012 the extraordinary period of validity of the 'after-effect' and the end of the coverage effect of numerous agreements was expected. Therefore, the potential risk that unions 
were facing if agreements were not reached was clear: leaving millions of workers without coverage and a further decreased space for job regulation. Accordingly, new agreements were reached after 2012 with retroactive effects, that it helped to maintain the coverage of collective bargaining and the union role in the regulatory space. However, following the contents of the II Agreement for Employment and Collective Bargaining vii , signed by the main unions and employer organisations, the outcome of these agreements resulted in very low or no wage increases, as Figure 1 shows.

\section{[Figure 2 about here]}

Hence, the effect of the regulatory change has been a clear change in the balance of power at the workplace level. Crucial in this modification of the power between actors at workplace level is the year 2012. The limitation of the 'after-effect' put strong pressures on unions, who had already seen their capacities to bargain strongly eroded due to the increased power brought to the employers by the reforms. In this regard, and in front of a system of collective bargaining that does not show drastic changes in terms of coverage and the importance of multi-employer agreements, the analysis of the dynamics in collective bargaining reveals the crucial role of the reforms implemented in weakening the capacities of unions and changing the balance of power at the workplace level.

\section{Conclusions and discussion}

This article has analysed the effect of a regulatory change in employees' working conditions and the dynamics of collective bargaining in Spain. The summary of the literature highlights how the effects of institutional changes will vary between institutional settings. The comparison using the EU-SILC data with the UK has shown that after the reforms the behaviour of the Spanish salaries came closer to the British liberal model. These trends were reinforced in both countries by freezes and cutbacks in salaries in the public sector. The EU-SILC panel data does not allow us to control for the public and private sector, but the Spanish data of the Structure of Earnings Survey suggests that decreases in salaries affected both public and private sectors. Furthermore, the data about the dynamic and processes of collective bargaining have shown that the behaviour of Spanish salaries has not been related to dramatic changes in the formal characteristics of collective bargaining. The coverage has remained high, and despite a trend towards single-employer agreements, multi-employer agreements have been maintained as the dominant ones. Two elements could have played a role here. First, the new legislation reinforced the power of firms by allowing them to opt-out of existing agreements at a higher level. According to Malo (2015a) from 2013 to 2015 significant opt-outs were reported representing an additional 18\% of workers covered by single-employer agreements in 2013 and $12 \%$ in 2014. Second, case study research has shown the interests of employers' organisations in maintaining the regulatory space as a way to maintain their own organisational interests (Fernandez Rodriguez et al, 2016). However, there have been substantial decreases in salary and increases below inflation in this period. In this regard, the findings suggest the need to consider the processes and dynamics inside formally unchanged institutional architectures.

This article contributes to current academic debates on liberalisation and employment institutions. The existing literature has characterised the regulatory change in Spain as change towards disorganised decentralisation and liberalisation of collective bargaining (Margisson et al, 2014; Meardi, 2014; and Picot and Tassinari, 2017) and our findings corroborate that the outcomes in terms of salaries after the reforms show a similar trend to the ones of the marketled model of the UK. However, this article provides further knowledge by demonstrating that these trends happened in a model that mantains high rates of collective bargaining coverage and the prevalence of multi-employer agreements. In terms of trajectories of liberalisation we can identify a double movement in Spain including 'instituional drift' and 'instituional conversion' (Thellen, 2009 and 2014). The system mantained its formal characteristics but its effectiveness decreased ('drift') due to the employers' use of opt-out clauses and the pressures introduced 
with the end of the after-effect period. In this context, the pressures to mantain the regulatory space (see further discussion below) led to multi-employer agreements with very low or negative pay increase ('conversion'). These findings are also in line with the arguments developed by Baccaro and Howell (2011) that highlight that same institutional characteristics can produce different outputs. In the Spanish case, multi-employer agreements and a high coverage of collective bargaining, which prevented unilateral employer responses in the first phase of the crisis were not an obstacle to the objectives of wage moderation and salary decreases in the second phase.

Crucially, the analysis has shown that the key element in this case is that the effect of the regulatory change should be analysed by considering not only the institutional characteristics of collective bargaining (coverage, coordination, etc.) but also the crucial modification of the balance of power between actors. Therefore, this article highlights the key role of the State and governments in reshaping employment relations (Heyes et al., 2012, Howell, 2016) and, more concretely, in modifying the balance of power and linkages between actors (McKenzie and Martinez Lucio, 2005). However, the results also suggest that the way a specific regulatory architecture reacts to a regulatory change towards employer unilateralism and the prevalence of single-employer agreements is strongly affected by pre-existing institutional patters and practices (Thelen, 2014). Accordingly, despite some increase, there has not been a clear trend towards single-employer agreements, as has been discussed above. Our conclusions should be treated with caution, as Spain suffered a drastic change and the different actors are adapting to an unknown terrain. More years and data are needed to fully understand the impact of the changes. Moreover, it should be further analysed how and if the main unions, weak at company level and with an institutional power diminished, are capable to develop different and innovative strategies. The III Agreement for Employment and Collective Bargaining, signed for 2015-2017, in a context of weak economic and employment recovery, follows the trend towards wage moderation and established maximum salary increases of 1\% (2015), 1.5\% (2016) and according to the GDP and other macro-economic magnitudes in 2017.

Second, the results crucially highlight the relevance of the dynamics and processes within institutional architectures. Moreover, they remark that the limitation of the 'after-effect' in 2012 played a crucial role in modifying unions' actions and practices. Crucially, the regulatory changes enhanced the capacity of employers to opt-out from existing multi-employer agreements that, together with the limitations in the 'after-effect', reduced their incentives to negotiate (Malo, 2015b). In this regard, and following Kelly (1998: 61), the results show that unions are not free agents when it comes to goals, methods or resources; other parties, particularly employers and the State, can constrain or suppress particular types of demands. Furthermore, and although the wage moderation guidelines established by the II AENC provided the basis for low wage increases, our data has shown that retroactive agreements included even more lower wage increases or even wage decreases. Therefore, practices and strategies of unions at workplace level should be understood against the specific context generated by the regulatory changes (MacKenzie, 2009), and by considering how a change in the balance of power affect the contents and expectations in the bargaining process. Hence, the reforms unilaterally imposed by the State destabilised practices embedded in the institutional architecture and actors and, crucially, modified the balance of power between actors. Crucially, in the Spanish case the fear of a real danger of a dramatic fall in collective bargaining coverage and potentially letting significant groups of workers without coverage, agreements were reached with very low or no salary increases. Significantly, the main unions named their manifesto in support of the II AENC with the message 'In Defence of Collective Bargaining', pointing out that sacrifices were done in order to keep the regulatory space and collective bargaining. Hence, in a context of weakened structural and associative power due to the ferocity and persistence of the crisis (Calavia and Rigby, 2016) the strategies of the main unions were focused on maintaining their institutional power. This should also be fully understood by highlighting the discretionary (and somewhat) strategic compromise to social dialogue and (weak) corporatist practices of the State in Spain (Martinez Lucio, 2007). However, this should not be understood 
as a passive acceptance of the situation by organised labour. The unilateral reforms were attacked by main unions, who called for three general strikes between 2010 and 2013 (Molina and Barranco, 2016). In parallel, a new repressive package to prevent protest (especially picketing during the strike) was passed, and union data indicates that 260 workers are facing court prosecution for actions during the strikes (CCOO and UGT, 2014), some of whom have been since imprisoned (El País, 15/07/2014). Herein, the regulatory change, some degree of employer unilateral practices at workplace level (López-Andreu, 2017), together with State repression, seem to have played a key role in modifying the capacities of action of industrial actors. These elements interacted with a weakened capacity of unions to mobilise and regulate in the periphery of Europe (Culpepper and Reagan, 2014).

Finally, the findings of this article remark that we need to pay special attention to the dynamics and processes in collective bargaining in analysing institutional changes and the outcomes of institutional architectures. Concretely, they show that it is especially needed to analyse the impact of changes on actors and on the dynamics established between actors (Mackenzie and Martinez Lucio, 2005 and 2014). By bringing these elements to the analysis, this article engages with Kelly's (1998:17) remarks regarding the institutionalist bias in the field of industrial relations. The author argues that our knowledge in the field consists of a great deal about the structure and scope of bargaining across different countries, about changes over time, and about the correlates of bargaining structure, with pay inequality, etc. By contrast, there is a lack of knowledge of politics and choices in the bargaining process. The aim of this article was not to analyse in detail the bargaining process. However, the findings provide evidence about how the regulatory changes have modified the outcomes and the dynamics of the bargaining process, and remark the need to analyse the changing formal and informal linkages between actors. In this regard, more research is needed, probably in the form of case studies and other qualitative techniques, to fully understand these processes and to enhance the knowledge about how actors shape their expectations, aims, and objectives under regulatory changes. 


\section{References}

Almond, Ph. (2011): "Nations, regions and international HRM" in Edwards, T. and Rees, Ch. (eds): International Human Resource Management. Globalization, national Systems and Multinational Companies. $2^{\text {nd }}$ Edition, Edinburgh: Pearson. Pp. 50-66.

Deakin S., Koukiadaki A. (2013): "The sovereign debt crisis and the evolution of labour law in Europe" in Countouris N., Freedland, M. (eds): Resocialising Europe in a Time of Crisis. Cambridge: Cambridge University Press. Pp. 163-188.

Banyuls, J., Miguelez, F., Recio, A., Cano, E., and Lorente, R. (2009): "The transformation of the employment system in Spain: towards a Mediterranean Neoliberalism", in Bosch, G., Lehndorff, S. and Rubery, J. (eds.): European Employment Models in Flux. A Comparison of Institutional Change in Nine European Countries. New York: Palgrave. Pp. 247-269.

Banyuls, J. and Recio, A. (2015): "A crisis inside the crisis: Spain under a conservative neoliberalism" in Lehndorff, S. (ed.): Divisive integration. The triumph of failed ideas in Europe - revisited, Brussels, European Trade Union Institute. Pp. 39-68.

Baccaro, L. and Howell, C. (2011): "A Common Neoliberal Trajectory: The Transformation of Industrial Relations in Advanced Capitalism”, Politics \& Society, 39 (4): 521-563.

Calavia, M.A. and Rigby, M. (2017): "Recursos de poder de los sindicatos en España. Su examen a través de la negociación colectiva", Sociología del Trabajo, Vol. 87: 7-24.

CCOO and UGT (2014): Manifiesto en defensa del Derecho de Huelga y de la Libertad Sindical!, 26/06/2014.

Culpepper, P.D and Reagan, A. (2014): "Why don't governments need trade unions anymore? The death of social pacts in Ireland and Italy", Socio-Economic Review, 12 (4): 723-745.

Crouch, C. (2014): "Introduction: labour markets and social policy after the crisis", Transfer, 20 (1): 7-22.

Deakin, S. and Koukiadaki, A. (2013): "The Sovereign Debt Crisis and the Evolution of Labour Law in Europe" in N. Countouris and M. Freedland (eds): Resocialising Europe in a Time of Crisis. Cambridge University Press, Cambridge. Pp. 163-188.

El País (2014) "Ingresa en prisión un activista del 15-M por un piquete en la huelga general", 15/07/2014.

Fernández-Rodríguez, C.J. and Martínez Lucio, M (2013): "Narratives, myths and prejudice in understandings employment systems: The case of rigidities dismissals and flexibility in Spain", Economic and Industrial Democracy, 34 (2): 313-336.

Fernández Rodríguez, C.J., Ibáñez, R. and Martínez Lucio, M. (2016): “Austerity and collective bargaining in Spain: The political and dysfunctional nature of neoliberal regulation", European Journal of Industrial Relations, 22 (3): 267-280.

Glassner, V., Keune, M. and Marginson. P. (2011): "Collective bargaining in a time of crisis: developments in the private sector in Europe", Transfer, 17 (3): 303-321. 
Grimshaw, D. (2012): “Austerity, Privatisation and levelling down: Public sector reforms in the United Kingdom" in Vaughan-Whitehead, D. (ed.): Public Sector Adjustments in Europe, Geneva: ILO. Pp. 576-626.

Grimshaw, D. and Rubery, J. (2012): "The end of the UK's liberal collectivist social model? The implications of the coalition government's policy during the austerity crisis", Cambridge Journal of Economics, 36 (1): 105-126.

Hall, P. and Gingerick, D. (2009): "Varieties of capitalism and institutional complementarities in the political economy", British Journal of Political Science, 39 (3): 449-482.

Hamann, K. (2012): The Politics of Industrial Relations: Labor Unions in Spain, London: Routledge

Hamann, K. and Martinez Lucio (2003): "Strategies of union revitalisation in Spain: negotiating change and fragmentation", European Journal of Industrial Relations, 9 (1): 7-24.

Hermann, C. (2014): "Structural Adjustment and neoliberal Convergence in labour Markets and Welfare: The Impact of the Crisis and Austerity measures on European Economic and Social Models", Competition and Change, 18 (2): 111-130.

Heyes, J. (2013): "Flexicurity in crisis: European labour market policies in a time of austerity", European Journal of Industrial Relations, 19 (1): 71-86.

Heyes, J., Lewis, P. and Clark, I. (2012): "Varieties of capitalism, neoliberalism and the economic crisis of 2008 -?”, Industrial Relations Journal, 43 (3): 222-241.

Howell, C. (2003): "Varieties of Capitalism: And Then There Was One?" Comparative Politics, 36 (1): 103-124.

Howell, C. (2016): "Regulating class in the neoliberal era: the role of the State in the restructuring of work and employment relations", Work, Employment and Society, 30 (4): 573 589.

Iversen, T. (2007): "Economic shocks and varieties of government responses", in B. Hanké, M. Rhodes and M. Thatcher (eds.) Beyond Varieties of Capitalism. Oxford: OUP. PP. 278-306.

Jackson, G. and Deeg, R. (2008): "Comparing capitalism: understanding institutional diversity and its implications for international business", Journal of International Business Studies, 39 (4): $540-561$.

Kelly, J. (1998) Rethinking Industrial Relations: Mobilization, Collectivism and Long Waves. London/New York: Routledge

Koukiadaki, A., Tavora, I. and Martinez Lucio, M. (2016): "Continuity and change in joint regulation in Europe: Structural reforms and collective bargaining in manufacturing", European Journal of Industrial Relations, 22 (3): 189-203.

Lallement, M. (2011): "Europe and the economic crisis: forms of labour market adjustment and varieties of capitalism", Work, Employment and Society, 25 (4): 627-641.

Locke, R. and Thelen, K. (1995): "Apples and Oranges Revisited: Contextualized Comparisons and the Study of Comparative Labor Politics", Politics \& Society, 23: 337-367.

López, I. and Rodriguez, E. (2011): “The Spanish Model”, New Left Review, 69: 5-29. 
López-Andreu, M. (2017): "All precarious? Institutional change and turning points in labour market trajectories in Spain: Insights from narrative biographies", Employee Relations, 39 (3): 408-422.

Malo, M. A. (2015a): "Los impactos de la reforma de 2012 en la negociación colectiva", Cuadernos de Información Económica, 245: 23-34.

Malo, M.A. (2015b): “The impact of Spain's 2012 labour reform on collective bargaining", Spanish Economic and Financial Outlook, 4 (3): 17-28.

Malo, M. A. (2016): "Collective bargaining reforms in Southern Europe during the crisis: impact in the light of international standards" in Pulignano, V., Köhler, H.D. and Stewart, P. (eds): Employment relations in an era of change. Multilevel challenges and responses in Europe. Brussels, European Trade Union Institute.

Marginson, P. (2014): "Coordinated bargaining in Europe: From incremental corrosion to incremental assault?" European Journal of Industrial Relations, 21 (2): 97-114.

Marginson, P. and Sisson, K. (2004): European Inregration and Industrial Relations. Basingstoke: Palgrave Macmillan.

Marginson, P. and Welz, C. (2015): "European wage-setting mechanisms under pressure: negotiated and unilateral change and the EU's economic governance regime", Transfer, 21 (84): 429-450.

Marginson, P., Keune, M. and Bohle, D. (2014): "Negotiating the effects of uncertainty? The governance capacity of collective bargaining under pressure", Transfer, 20 (1): 37-51.

Martínez Lucio, M. (1999) "Spain: Regulating Employment and Social Fragmentation", in A. Ferner and R. Hyman (eds) Changing Industrial Relations in Europe. Malden, MA: Blackwell. Pp. 426-458.

Martinez Lucio, M. (2017): "Uncertainity and undecidability in the contemporary State: the dualist and complex role of the State in Spanish labour and employment regulations in the age of "flexibility", in Grimshaw, D., Fagan, C., Hebson, G. and Tavora, I. (eds): Making Work More Equal. A new labour market segmentation approach. Manchester: Manchester University Press. Pp. 288-308.

Meardi, G. (2014) "Employment relations under external pressure: Italian and Spanish reforms in 2010-12" in Hauptmeier M, Vidal M (eds) Comparative Political Economy of Work. Basingstoke: Palgrave Macmillan, Pp. 332-350

MacKenzie, R. (2009): "Union Responses to Restructuring and the Growth of Contingent Labour in the Irish Telecommunications Sector". Economic and Industrial Democracy, 30 (4): $539-563$.

MacKenzie, R., \& Martinez Lucio, M. (2005): "The realities of regulatory change: Beyond the fetish of deregulation" Sociology, 39(3), 499-517

MacKenzie, R., and Martinez Lucio, M. (2014): "The colonisation of employment regulation and industrial relations?: Dynamics and developments over five decades of change. Labor History, 189-207 
Molina, O. (2014): "Self-regulation and the State in industrial relations in Southern Europe: Back to the future?", European Journal of Industrial Relations, 20 (1): 21-36.

Molina, O. and Barranco, O. (2016): "Trade union strategies to enhance strike effectiveness in Italy and Spain", Transfer, 22 (3): 383 - 399

Molina, O and Miguélez, F. (2013): "From negotiation to imposition: Social dialogue in austerity times in Spain", ILO Working Paper no 51.

Molina, O. \& Rhodes, M. (2007) "The political economy of adjustment in mixed market economies: A study of Spain and Italy" in Hancké, B., Rhodes, M. and Thatcher, M., (eds): Beyond Varieties of Capitalism: Conflict, Contradictions and Complementarities in the European Economy. Oxford: Oxford University Press, Pp. 223-52

Muñoz de Bustillo, R. and Antón, J-I. (2011): "From the highest employment growth to the deepest fall: Economic crisis and labour inequalities in Spain", Vaughan-Whitehead, D. (ed.): Work inequalities in the crisis. Evidence from Europe. Cheltenham: Edward Elgar. Pp. 397-448.

Muñoz de Bustillo, R. and Antón, J-I. (2013) "Those Were the Days, My Friend: The Public Sector and the Economic Crisis in Spain", Vaughan-Whitehead, D. (ed.): Public Sector sock. The Impact of Policy Retrenchment in Europe, Cheltenham: Edward Elgar. Pp. 511-542.

Pérez-Infante, J. (2015): "Las reformas de la negociación colectiva y la devaluación salarial desde una perspectiva económica: naturaleza y resultados", Temas Laborales, 120: 35-83.

Picot, G. and Tassinari, A. (2017): "All of one kind? Labour market reforms under austerity in Italy and Spain”, Socio-Economic Review, 15 (2): 461-482.

Prosser, T. (2015): "Dualization or liberalization? Investigating precarious work in eight European countries", Work, Employment and Society, 30 (6): 949-965.

Rocha, F. (2014): "Crisis and Austerity Policies in Spain: towards an authoritarian model of industrial relations" in Rocha, F (ed) The New EU Economic Governance and its Impact on the National Collective Bargaining Systems. Madrid: CCOO. Pp. 175-204

Rubery, J., and Grimshaw, D. (2003). The Organisation of Employment: an international perspective. London: Palgrave

Thellen, C. (2009): "Institutional Change in Advanced Political Economies", British Journal of Industrial Relations, 47 (3): 471-498.

Thellen, C. (2014): Varieties of Liberalization and the New Politics of Social Solidarity, Cambridge, Cambridge University Press.

Schulten, T. and Müller, T. (2015): "European economic governance and its intervention in national wage development and collective bargaining", in Lehndorff, $\mathrm{S}$ (ed.), Divisive integration. The triumph of failed ideas in Europe - revisited, Brussels, European Trade Union Institute. Pp. 331-363.

Traxler, F. (1995): "Farewell to labour market associations?" in Crouch, C. and Traxler, F. (eds): Organised Industrial Relations in Europe. What future? Aldershot: Abewury.

Van Wanrooy, B.; Bewley, H.; Bryson, A.; Forth, J.; Freeth, S.; Stokes, L.;. and Wood, S. (2014): The 2011 Workplace Employment Relations Study First findings", Economic and Social Research Council. Available on: 
https://www.gov.uk/government/uploads/system/uploads/attachment_data/file/336651/bis-141008-WERS-first-findings-report-fourth-edition-july-2014.pdf (accessed 06/07/2017)

Vaughan-Whitehead, D. (ed.) (2013): Public Sector sock. The Impact of Policy Retrenchment in Europe, Cheltenham: Edward Elgar.

Visser, J. (2016): "What happened to collective bargaining during th great recession?", IZA Journal of Labor Policy, 5 (9): 1-35.

Warren, T. (2015): "Work-time underemployment and financial hardship: class inequalities and recession in the UK", Work, Employment and Society, 29 (2): 191-212.

\section{Tables and figures}

Figure 1: Changes in salary and working time between $t$ and $t-1$ by period. Spain and the UK. 2004/5-2013 + 


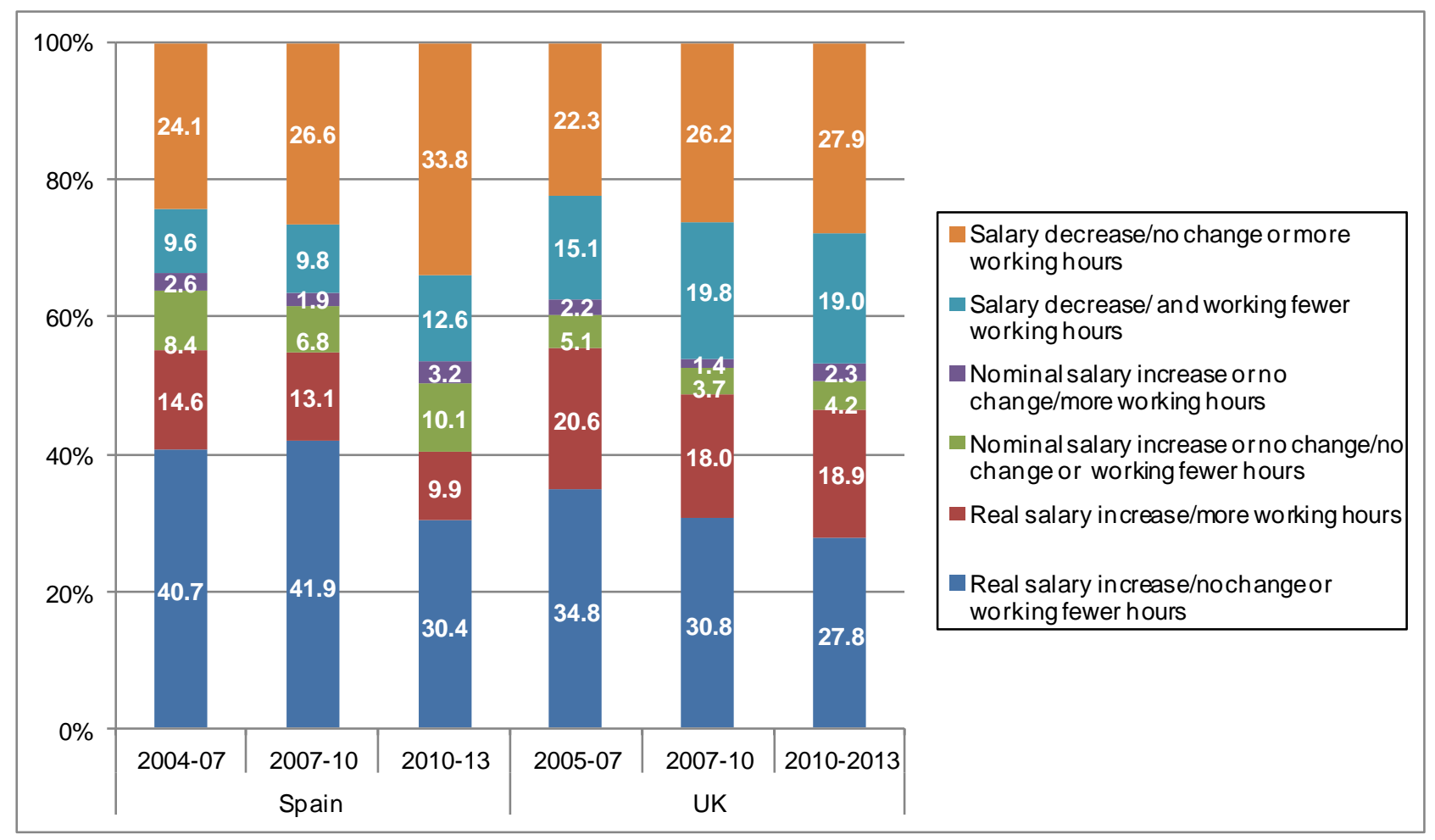

†The valid number of observations for Spain was: 11,035 for 2004-2007, 13,134 for 2007-2010, and 10,044 for 2010-2013. And for the UK: 5,865 for 2004-2007, 5,102 for 2007-2010 and 7,444 for 20102013

Source: Own elaboration based in EU-SILC (Eurostat)

Table 1: Collective agreements in force by type and workers affected (2007-2015). Spain

\begin{tabular}{|c|c|c|c|c|c|c|c|c|}
\hline & $\begin{array}{l}\text { Firm-level } \\
\text { agreements }\end{array}$ & $\begin{array}{l}\text { Affected } \\
\text { workers }\end{array}$ & $\begin{array}{c}\text { Higher level } \\
\text { agreements }\end{array}$ & $\begin{array}{l}\text { Affected } \\
\text { workers }\end{array}$ & $\begin{array}{l}\% \text { firm level } \\
\text { on total } \\
\text { agreements }\end{array}$ & $\begin{array}{c}\% \text { workers } \\
\text { affected by } \\
\text { firm level on } \\
\text { total workers } \\
\text { covered }\end{array}$ & $\begin{array}{c}\text { Total } \\
\text { coverage } \dagger\end{array}$ & $\begin{array}{c}\text { Coverage } \\
\text { without } \\
\text { retroactive } \\
\text { agreements } \ddagger\end{array}$ \\
\hline 2007 & 4598 & 1261064 & 1418 & 10345405 & 76.4 & 10.9 & 77.3 & na \\
\hline 2008 & 4539 & 1215274 & 1448 & 10752874 & 75.8 & 10.2 & 77.1 & na \\
\hline 2009 & 4323 & 1114596 & 1366 & 10443230 & 76 & 9.6 & 79.2 & na \\
\hline 2010 & 3802 & 923222 & 1265 & 9871112 & 75 & 8.6 & 75.2 & na \\
\hline 2011 & 3422 & 928995 & 1163 & 9733788 & 74.6 & 8.7 & 75.4 & na \\
\hline 2012 & 3234 & 925744 & 1142 & 9173275 & 73.9 & 9.2 & 74 & 54.2 \\
\hline 2013 & 3395 & 932746 & 1194 & 9332656 & 74 & 9.1 & 77.8 & 73.9 \\
\hline 2014 & 4004 & 867243 & 1181 & 9437457 & 77.2 & 8.4 & 77 & 70.5 \\
\hline 2015 & 4493 & 846930 & 1149 & 9380348 & 79.6 & 6.1 & 74.1 & 67.7 \\
\hline
\end{tabular}

†Calculated following Pérez-Infante (2015:22-23) as total workers covered by agreements divided by employees registered in Social Security.

$\ddagger$ Calculated following above but only considering agreements reached before and during the year (excluding retroactive agreements). Information only available since 2012.

Source: Own elaboration based in Statistics on Collective Agreements and Social Security Register (Employment and Social Security Ministry)

Figure 2: Pay rise agreed in collective agreements by type of agreement. 2007-2015 


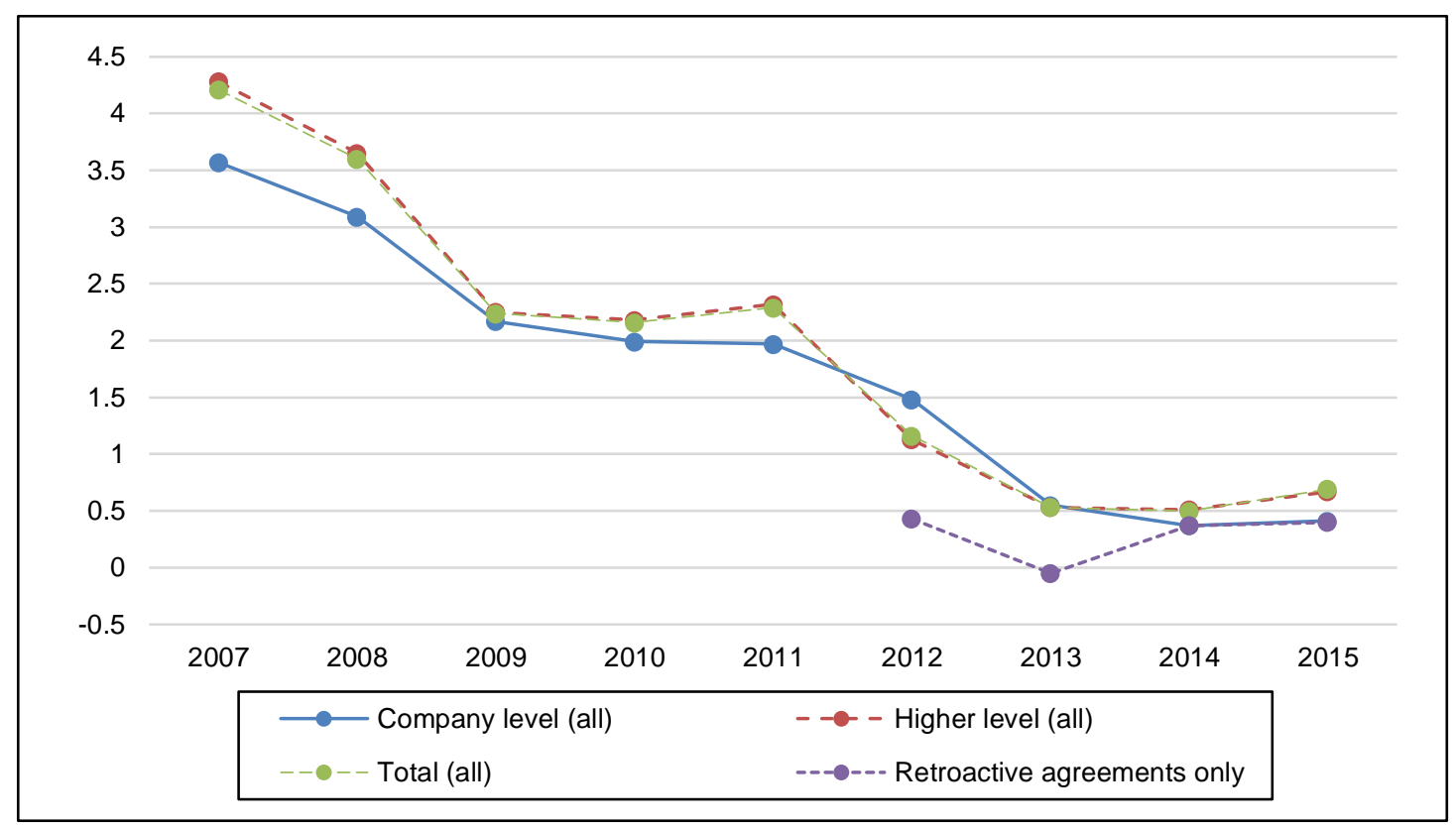

Source: Statistics on Collective Agreements (Employment and Social Security Ministry)

\footnotetext{
${ }^{i}$ The data in this paragraph is based on the Labour Force Survey (Eurostat). Calculations have been carried out by the author.

ii The 'after-effect' makes that regulations continue to apply after agreements have expired, what encourage employers to negotiate a new agreement (Hermann, 2014).

iii In parallel, and in line with the official narrative of the reforms to reduce dualisation, there was an increase of dismissal costs for temporary contracts from 8 to 12 days' salary per year worked.

${ }^{\text {iv }}$ Using the Harmonised Index of Consumer prices provided by Eurostat.

v Own calculations by the author using the Structure of Earnings Survey - Encuesta de Estructura de Salarios (INE) for 2010 and 2013.

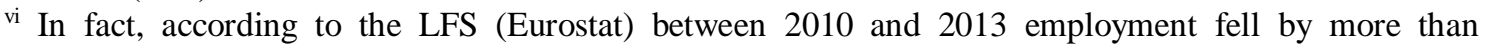
$1,500,000$ and unemployment rate increased from the $20 \%$ to the $26.1 \%$.

vii The agreement established guidelines about the content of collective bargaining, including maximum wage increases of $0.5 \%$ (2012), $0.6 \%$ (2013) and between $0.6 \%$ and $1.5 \%$ in 2014 according to GDP evolution and other macroeconomic factors.
} 